\title{
Ekstraksi Fitur Berdasarkan Deskriptor Bentuk dan Titik Salien Untuk Klasifikasi Citra Ikan Tuna
}

\author{
Ratri Enggar Pawening1, Agus Zainal Arifin², Anny Yuniarti \\ ${ }^{1}$ Jurusan Teknik Informatika, Sekolah Tinggi Teknologi Nurul Jadid \\ Jl. Pondok Pesantren Nurul Jadid, PO BOX 1, Paiton, Probolinggo 67291 \\ 2,3 Jurusan Teknik Informatika, Fakultas Teknologi Informasi, Institut Teknologi Sepuluh Nopember \\ Jl. Teknik Kimia, Sukolilo, Surabaya 60117 \\ Email: ${ }^{1}$ enggar.r@gmail.com, ${ }^{2}$ agusza@cs.its.ac.id, ${ }^{3}$ anny@if.its.ac.id
}

Masuk: 19 Januari 2016; Direvisi: 1 Februari 2016; Diterima: 2 Februari 2016

\begin{abstract}
The manual classification of fish causes problems on accuracy and execution time. In the image of tuna, beside the shape feature, local features is also necessary to differentiate the types of fish especially which have a similar shape. The purpose of this study is to develop a new feature extraction system which integrates point of saline and the shape of descriptor to classify the image of tuna. The input image is then transformed into HSV format. Hue channel is selected for the segmentation process. Shape descriptors are extracted by using Fourier Descriptor (FD) and the saline points are extracted using Speeded Up Robust Features (SURF). The results of local features are performed by Bag of Feature (BOF). Feature integration combines shape descriptor and saline features with appropriate weight. Experimental results show that by integrating features, the classification problems of fish with similar shape can be resolved with an accuracy of classification acquired by $83.33 \%$.
\end{abstract}

Keywords: feature extraction, fourier descriptor, surf, classification, tuna fish image

\begin{abstract}
Abstrak. Klasifikasi secara manual yang dilakukan berdasarkan bentuk, tekstur, dan bagian tubuh ikan dapat menimbulkan permasalahan pada akurasi dan waktu klasifikasi. Pada citra ikan tuna, selain diperlukan fitur bentuk juga diperlukan fitur lokal untuk membedakan jenis ikan terutama yang memiliki bentuk secara visual mirip. Tujuan penelitian ini adalah mengembangkan sistem ekstraksi fitur baru yang mengintegrasikan deskriptor bentuk dan titik salien untuk klasifikasi citra ikan tuna. Segmentasi diawali dengan mengambil kanal Hue pada citra HSV. Deskriptor bentuk diekstrak menggunakan Fourier Descriptor dan titik salien diekstrak menggunakan Speeded Up Robust Features. Untuk menyamakan dimensi dilakukan pemrosesan menggunakan Bag of Feature. Kedua jenis fitur yang sudah diperoleh dilakukan integrasi dengan mempertimbangkan bobot masing-masing fitur. Uji coba dilakukan pada dataset tiga jenis ikan tuna dengan 10-fold cross validation. Hasil uji coba menunjukkan dengan mengintegrasikan deskriptor bentuk dan titik salien permasalahan klasifikasi ikan tuna dengan bentuk yang mirip dapat diselesaikan dengan akurasi klasifikasi sebesar 83,33\%.
\end{abstract}

Kata Kunci: ekstraksi fitur, deskriptor fourier, surf, klasifikasi, citra ikan tuna

\section{Pendahuluan}

Pada tahun 2014 produksi tangkap ikan tuna mencapai 310.560 ton dengan nilai ratarata peningkatan dalam lima tahun terakhir 3,75\%. Dari nilai tangkap yang selalu bertambah setiap tahunnya, menjadikan ikan tuna sebagai objek yang menarik untuk diteliti.

Tuna adalah ikan laut yang terdiri dari beberapa spesies dari famili Scombridae, terutama genus Thunnus. Jenis tuna di Indonesia antara lain yellowfin, bigeye, skipjack, bluefin, albacore, dan small tuna. Jenis yang paling banyak ditangkap adalah yellowfin, bigeye, dan skipjack. Untuk membedakan jenis ikan tuna, selain berdasarkan bentuk juga dapat dilihat berdasarkan tekstur dan bagian tubuh ikan. Jenis tuna skipjack memiliki tekstur yang sangat berbeda dengan jenis yang lain, sedangkan jenis bigeye dan yellowfin memiliki tekstur yang mirip. Kedua jenis ikan tersebut dapat dibedakan berdasarkan kelonjongan bentuknya. Berdasarkan warna, ketiga jenis ikan tersebut tidak memiki warna yang beragam yang dapat membedakan jenisnya. Selain melihat faktor bentuk, tekstur, dan warna, bagian tubuh ikan 
dapat dijadikan sebagai instrumen pembeda. Adapun bagian tubuh yang dapat membedakan adalah bentuk dan panjang sirip, bentuk kepala, mata, dan ekor.

Pada penelitian yang sebelumnya untuk klasifikasi ikan dilakukan dengan melihat deskriptor kontur secara global untuk melihat ketidaksamaan bentuk. Penelitian ini lebih menitikberatkan pada jenis ikan yang mempunyai perbedaan signifikan. Pada penelitian ini mecoba untuk melakukan klasifikasi pada jenis ikan yang mempunyai kemiripan bentuk. Dengan bentuk yang mirip tersebut, diperlukan informasi tambahan berupa fitur lokal yang direpresentasikan berupa titik salien agar menjadi fitur yang signifikan untuk proses klasifikasi.

Ikan tuna hasil tangkap akan diolah di perusahaan pengolahan ikan menjadi produk olahan maupun ikan segar. Bagi perusahaan pengolahan ikan perlu dibuat sistem otomatisasi untuk pemisahan jenis ikan tuna. Pada sistem pemisahan manual yang sering terjadi adalah kesalahan pemisahan dan waktu pemisahan yang tidak stabil, karena sangat bergantung dari keterampilan pegawainya. Kesalahan pemisahan jenis dan ukuran dapat menyebabkan kegagalan di bagian produksi seperti ketidakseragaman tingkat kematangan produk, kesalahan proses memasak, yang dapat mengakibatkan kerugian di sektor finansial. Pada citra ikan tuna, selain diperlukan fitur bentuk juga diperlukan fitur lokal untuk membedakan jenis ikan terutama yang memiliki bentuk secara visual mirip.

Tujuan penelitian ini adalah mengembangkan sistem ekstraksi fitur baru yang mengintegrasikan deskriptor bentuk dan titik salien untuk klasifikasi citra ikan tuna. Diharapkan pengintegrasian ini memperoleh fitur yang signifikan yang dapat meningkatkan akurasi klasifikasi.

\section{Tinjauan Pustaka}

\subsection{Penelitian Terkait}

Ekstraksi fitur low level dilakukan dengan membedakan objek berdasarkan karakteristik warna, bentuk, dan tekstur (El-gayar \& Soliman, 2013). Bentuk direpresentasikan dalam dua kategori, yaitu berdasarkan region (Chen \& Sun, 2010) dan berdasarkan kontur (Hu, 1962). Selain SSD, Aakif \& Khan (2015) melakukan penelitian menggunakan metode lain yang digunakan adalah shape signature dan spectral descriptor. Shape signature merupakan representasi lokal dari fitur bentuk yang sangat sensitif terhadap noise. Metode ini perlu dilakukan penanganan lebih lanjut salah satunya menggunakan spectral transform seperti Fourier transform atau wavelet transform (Nabizadeh \& Kubat, 2015) (Kadir, 2015). Yang, dkk. (2014) mengambil fitur lokal berupa titik-titik penting dari citra menggunakan SURF untuk sistem temu kembali citra. Hasil pengujian menunjukkan fitur yang digunakan memiliki performa yang baik pada proses pencarian.

\subsection{Ekstraksi Deskriptor Bentuk}

\subsubsection{Shape Signature}

Shape signature merupakan cara untuk merepresentasikan batas tepi 2D menggunakan fungsi 1D. Cara ini digunakan untuk mendeskripsikan bentuk dan mengambil fitur pada bentuk. Shape signature yang sering digunakan adalah centroid distance, complex coordinate, dan curvature function $(\mathrm{Hu} \& \mathrm{Li}, 2013)$. Fungsi centroid distance merupakan jarak antara titik tepi dengan centroid. Koordinat centroid $\left(\mathrm{x}_{\mathrm{c}}, \mathrm{y}_{\mathrm{c}}\right)$ diperoleh dengan menggunakan persamaan (1) dan (2). Koordinat centroid $\left(\mathrm{x}_{\mathrm{c}}, \mathrm{y}_{\mathrm{c}}\right)$ diperoleh dari rata-rata semua koordinat piksel tepi $(\mathrm{x}(\mathrm{t}), \mathrm{y}(\mathrm{t}))$ dari titik tepi yang ditemukan sebanyak $\mathrm{N}$ titik tepi. Pada metode centroid distance, jarak antara titik tepi hingga centroid $\left(\mathrm{x}_{\mathrm{c}}, \mathrm{y}_{\mathrm{c}}\right)$ pada objek dirumuskan pada persamaan (3).

$$
\begin{aligned}
& \mathrm{x}_{\mathrm{c}}=\frac{1}{N} \sum_{t=0}^{N-1} x(t) \\
& \mathrm{y}_{\mathrm{c}}=\frac{1}{N} \sum_{t=0}^{N-1} y(t)
\end{aligned}
$$




$$
r(t)=\left(\left[x(t)-x_{c}\right]^{2}+\left[y(t)-y_{c}\right]^{2}\right)^{1 / 2}, t=0,1, \ldots, N-1
$$

\subsubsection{Fourier Descriptor}

Pada perhitungan FD, $F(x, y)$ merupakan citra biner yang berukuran $M x N$. Citra berisi objek tunggal. Boundary tracing algorithm digunakan untuk menghitung piksel tepi dari objek yang berisi informasi geometri dari kontur objek. Umumnya FD 1 dimensi diperoleh melalui Fourier Transform (FT) pada fungsi shape signature yang diperoleh dari koordinat piksel tepi ke- $t$ hingga seluruh piksel tepi sejumlah $\mathrm{N}\{(\mathrm{x}(\mathrm{t}), \mathrm{y}(\mathrm{t}), \mathrm{t}=0,1, \ldots, \mathrm{N}-1)\}$. FT satu dimensi diaplikasikan pada jarak centroid $\mathrm{r}(\mathrm{t})$ untuk memperoleh koefisien FT yang dirumuskan pada persamaan (4). Magnitude koefisien $\mathrm{a}_{\mathrm{n}}(\mathrm{n}=0,1, \ldots, \mathrm{N}-1)$ yang dinormalisasi oleh magnitude koefisien pertama $\mathrm{a}_{0}$ digunakan sebagai shape descriptor yang disebut FD, ditunjukkan pada persamaan (5). FD yang sudah dinormalisasi bersifat invarian terhadap translasi, rotasi, dan skala. Vektor dari Sn merupakan deskriptor bentuk.

$$
\begin{aligned}
& a_{n}=\frac{1}{N} \sum_{t=0}^{N-1} r(t) \exp \left(\frac{-j 2 \pi n t}{N}\right), n=0,1, \ldots, N-1 \\
& S_{n}=\left|\frac{a_{n}}{a_{0}}\right|, n=0,1, \ldots, N-1
\end{aligned}
$$

\subsection{Speeded Up Robust Features (SURF)}

\subsubsection{Detektor Titik Salien}

SURF menggunakan detektor fitur berbasis matriks Hessian untuk menemukan titik salien. Matriks Hessian digunakan sebagai detektor pada SURF karena mempunyai performa yang baik dalam waktu komputasi dan akurasi (Bay, dkk., 2008). Determinan dari matriks Hessian digunakan untuk menentukan lokasi dan skala deskriptor. Untuk titik $\mathrm{x}=(\mathrm{x}, \mathrm{y})$ pada sebuah citra I, matriks Hessian $\mathrm{H}(\mathrm{x}, \sigma)$ titik x pada skala $\sigma$ didefinisikan pada persamaan (6). Determinan matriks Hessian menandakan sejauh mana respon dan ekspresi dari perubahan lokal sekitar area. $\mathrm{L}_{\mathrm{xx}}(\mathrm{x}, \sigma)$ merupakan konvolusi citra I di titik $\mathrm{x}$ dengan turunan orde dua Gaussian $\frac{\partial^{2}}{\partial x^{2}} g(\sigma)$, begitu juga untuk nilai $\mathrm{L}_{\mathrm{xy}}(\mathrm{x}, \sigma)$ dan $\mathrm{L}_{\mathrm{yy}}(\mathrm{x}, \sigma)$.

$$
H(x, \sigma)=\left[\begin{array}{ll}
L_{x x}(x, \sigma) & L_{x y}(x, \sigma) \\
L_{x y}(x, \sigma) & L_{y y}(x, \sigma)
\end{array}\right]
$$

SURF melakukan pendekatan turunan orde dua Gaussian dengan kotak filter. Konvolusi citra dengan filter dapat dilakukan dengan cepat menggunakan citra integral. Pendekatan dilambangkan dengan $\mathrm{D}_{\mathrm{xx}}, \mathrm{D}_{\mathrm{xy}}$, dan $\mathrm{D}_{\mathrm{yy}}$ yang menggantikan $\mathrm{L}_{\mathrm{xx}}, \mathrm{L}_{\mathrm{xy}}$, dan $\mathrm{L}_{\mathrm{yy}}$. Gambar 1 merupakan kotak filter berukuran 9x9 dengan $\sigma=1,2$ yang merepresentasikan skala terkecil. Ilustrasi area abu-abu mempunyai nilai kernel 0 , putih positif, dan hitam negatif. Filter ini selanjutnya dikonvolusi dengan citra I pada titik $\mathrm{x}$.

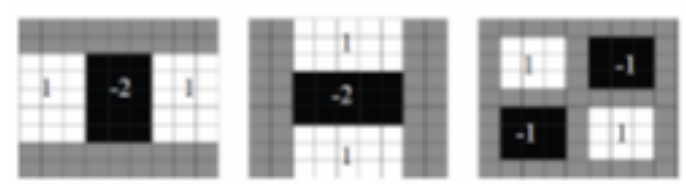

Gambar 1. Kotak Filter

Determinan dari pendekaan matriks Hessian dihitung menggunakan persamaan (7). Bobot $w$ digunakan untuk menyeimbangkan $\operatorname{det}\left(\mathrm{H}_{\text {approx }}\right)$, yang merupakan energi dari Gaussian. Secara teori, w bernilai konstan 0,9 . 
$\operatorname{det}\left(H_{\text {approx }}\right)=D_{x x} D_{y y}-\left(w D_{x y}\right)^{2}$

\subsubsection{Deskriptor Titik Salien}

Untuk memberikan deskriptor pada fitur blob, Haar wavelet response pada arah $\mathrm{x}$ dan $\mathrm{y}$ di dalam area lingkaran dengan radius 6 s di sekitar titik salien $\mathrm{p}=(\mathrm{x}, \mathrm{y})$ dihitung untuk skala $\sigma$ yang berbeda, s adalah skala dimana titik salien ditemukan. Jumlah wavelet response vertikal dan horizontal dihitung pada area yang diamati, selanjutnya mengubah orientasi area yang diamati (menambahkan phi/3), dan melakukan perhitungan kembali sampai menemukan orientasi dengan jumlah terbanyak. Orientasi ini selanjutnya menjadi orientasi utama dari deskriptor fitur. Wavelet response dibobotkan menggunakan Gaussian orde dua dengan $\sigma=2 \mathrm{~s}$. Response direpresentasikan sebagai titik-titik di koordinat yang berpusat di titik salien. Orientasi yang dominan diperkirakan dengan menghitung jumlah semua response di dalam area orientasi 60 .

Untuk mengekstrak deskriptor, buat area kotak yang berpusat di titik salien dengan orientasi yang sudah diperoleh pada proses sebelumnya. Ukuran dari window adalah 20s, s adalah skala dimana titik salien ditemukan. Area window dibagi lagi menjadi sub yang lebih kecil berukuran $4 \times 4$, dimana setiap sub region dihitung Haar wavelet response pada $5 \times 5$ titik sampel. Komponen yang digunakan dalam perhitungan ditunjukkan pada Gambar 2. Wavelet response $\mathrm{dx}$ dan dy dijumlahkan di setiap sub region. Untuk menemukan informasi mengenai polarity dan perubahan intensitas, maka jumlah nilai absolut response $|\mathrm{dx}|$ dan $|\mathrm{dy}|$ juga diambil. Masing-masing sub region memiliki empat dimensi untuk vektor deskriptor v untuk intensitas dengan struktur $\mathrm{v}=\{\Sigma \mathrm{dx}, \Sigma|\mathrm{dx}|, \Sigma \mathrm{dy}, \Sigma|\mathrm{dy}|\}$, sehingga menghasilkan vektor deskriptor untuk satu titik salien yang memiliki $4 \times 4$ sub region sebanyak 64 .

\subsection{Bag of Feature (BOF)}

Algoritma BOF memiliki tiga bagian utama, yaitu: ekstraksi fitur dan transformasi deskriptor fitur, pembangunan visual dictionary, dan klasifikasi (Li, dkk., 2015). Tahapan dari BOF yaitu: (1) Melakukan ekstraksi fitur berupa titik salien. Dalam penelitian ini menggunakan metode SURF. Setiap fitur atau titik yang ditemukan memiliki 64 dimensi vektor fitur yang disebut dengan deskriptor. (2) Semua fitur yang berhasil ditemukan dalam semua data training dilakukan pengklasteran. Pada penelitian ini menggunakan K-means clustering dengan centroid yang dapat ditentukan dengan cara random. (3) Pada proses pembangunan visual dictionary, setiap citra dibangun histogram yang menggambarkan jumlah fitur di dalam kelas klaster. (4) Representasi dari histogram ini dijadikan sebagai fitur input pada proses klasifikasi.

\section{Metode Penelitian}

Gambaran umum metode penelitian dan kontribusi ditunjukkan pada Gambar 2. Garis putus-putus menunjukkan area kontribusi. Proses utama pada penelitian ini terdiri dari segmentasi, ekstraksi deskriptor bentuk, ekstraksi titik salien, integrasi fitur, dan klasifikasi.

\subsection{Segmentasi}

Pada penelitian ini pemisahan antara objek dengan background perlu dilakukan untuk menurunkan komputasi ketika proses ekstraki fitur. Pada tahap ini, citra input RGB dilakukan segmentasi untuk memisahkan objek dengan background. Tahapan segmentasi yang dilakukan antara lain: (1) Mentransformasi citra input RGB menjadi HSV. (2) Mengambil kanal Hue (H) tanpa kanal Saturation (S) dan Value (V). (3) Mengubah citra $\mathrm{H}$ menjadi citra biner. (4) Melakukan proses morfologi untuk menghilangkan noise sehingga mendapatkan hasil segmentasi yang terbaik.

Output dari proses segmentasi ini adalah objek yang sudah terpisah dengan backgroud dalam bentuk citra biner. Citra biner dijadikan masukan untuk proses ekstraksi deskriptor bentuk. Untuk keperluan uji coba pada ekstraksi deskriptor bentuk, citra biner hasil segmentasi dibagi menjadi tiga bagian, yaitu segmentasi tubuh ikan utuh, segmentasi bagian kepala, dan 
segmentasi bagian ekor. Sebagai input pada proses ekstraksi titik salien, hasil segmentasi objek berupa citra grayscale.

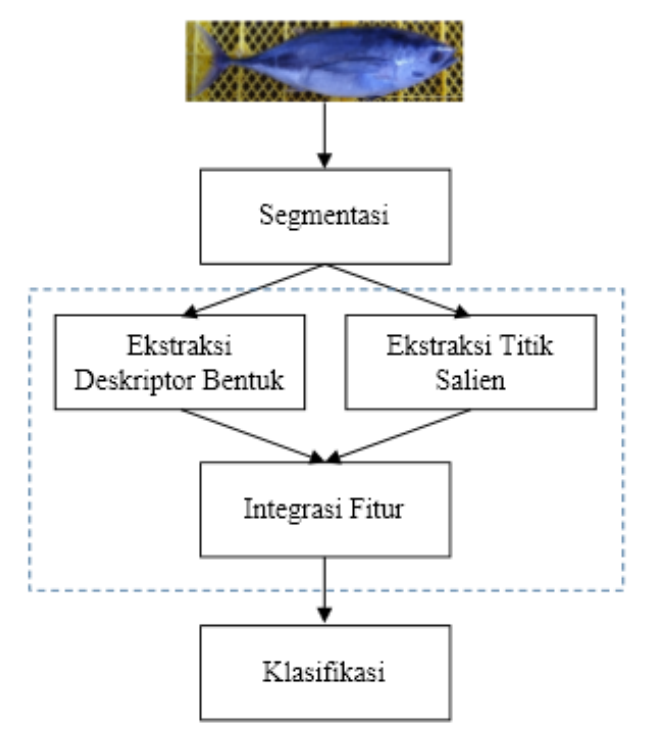

Gambar 2. Metode Penelitian dan Kontribusi

\subsection{Ekstraksi Deskriptor Bentuk}

FD digunakan untuk mengekstrak deskriptor bentuk. Tahapan untuk mendapatkan deskriptor bentuk antara lain: (1) Menentukan piksel tepi. Pada proses ini menggunakan algoritma boundary tracing Moore-Neighbor Tracing. (2) Menentukan centroid. Piksel centriod diperlukan untuk menghitung centroid distance. Koordinat $\mathrm{x}$ dan y titik centroid dapat dihitung dengan persamaan (1) dan persamaan (2) yang merupakan rata-rata dari koordinat titik tepi. (3) Menentukan jumlah titik tepi yang tepat. Proses klasifikasi memerlukan jumlah fitur yang tetap. Titik tepi dari objek dapat diketahui dari hasil segmentasi. Untuk citra yang berbeda akan menghasilkan segmentasi yang berbeda dengan jumlah titik tepi yang berbeda. Sehingga diperlukan penetapan jumlah titik tepi agar semua data training dan data testing memiliki dimensi yang sama. Penentuan titik tepi dilakukan dengan metode equal arclength sampling. Kandidat titik berikutnya $\mathrm{x}$ ' diperoleh dari hasil perbandingan perimeter tepi bentuk $\mathrm{P}$ dengan jumlah titik yang ditentukan K. (4) Mengitung centroid distance. Centroid distance merupakan shape signature yang digunakan oleh FD di penelitian ini. Jarak dihitung dari titik centroid dengan titik tepi yang sudah ditentukan pada proses (3) menggunakan persamaan (3). (5) Menghitung koefisien FD. Koefisien FD dihitung pada setiap jarak yang sudah diperoleh di tahap sebelumnya menggunakan persamaan (4). (6) Menormalisasi koefisien FD. Koefisien pertama digunakan untuk menormalisasi semua koefisien Fourier yang dirumuskan pada persamaan (5). Nilai koefisien yang sudah dinormalisasi merupakan nilai deskriptor bentuk.

\subsection{Ekstraksi Titik Salien}

Metode SURF digunakan untuk mendapatkan titik salien pada citra ikan. Tahapan untuk mendapatkan titik salien antara lain: (1) Mendeteksi titik salien. Citra input adalah citra objek grayscale. Setiap piksel dihitung nilai Dxx, Dyy, dan Dxy yang diperoleh dari hasil konvolusi antara citra input pada piksel $x$ dengan filter Gaussian Lxx, Lyy, dan Lxy. Nilai determinan matriks Hessian dihitung menggunakan persamaan (7). Selanjutnya dilakukan proses lokalisasi titik salien dengan pendeteksian nilai ektrema (nilai maksima atau minima yang dibandingkan dengan tetangganya). Proses lokalisasi calon fitur dilakukan dengan mencari lokasi calon fitur pada setiap ruang skala dengan menggunakan metode non-maximum supression terhadap extrema dari determinan matriks Hessian. Titik yang memiliki nilai ekstrema merupakan titik salien yang dicari. (2) Menentukan descriptor. Setiap titik salien yang ditemukan diekstrak 
untuk mendapatkan deskripsi fitur yang unik dan robust. Terdapat 16 window untuk mendapatkan deskriptor. Setiap window memliki empat nilai, yaitu dx, dy, $|\mathrm{dx}|$, dan $|\mathrm{dy}|$, sehingga total deskriptor tiap titik salien ada 64 deskriptor fitur. (3) BOF. Jumlah titik salien yang berhasil ditemukan di setiap citra training berbeda-beda. Sehingga untuk keperluan klasifikasi diperlukan jumlah fitur yang tetap. Metode BOF dapat mengatasi permasalahan ini. Dimana semua fitur yang berhasil ditemukan dalam semua data training dilakukan pengklasteran. Pada penelitian ini menggunakan K-Means clustering dengan centroid yang dapat ditentukan dengan cara random. Jumlah klaster menandakan jumlah visual dictionary. Jumlah klaster awal ditentukan tiga kelas, untuk selanjutnya penentuan jumlah klaster akan diubah pada proses uji coba. Frekuensi titik salien sebagai anggota klaster direpresentasikan dalam bentuk histogram. Pada proses ini menghasilkan fitur lokal titik salien sejumlah $\mathrm{K}$ (jumlah klaster).

\subsection{Integrasi Fitur}

Pada tahap ini dilakukan proses penggabungan antara deskriptor bentuk dan titik salien. Kedua fitur akan dilakukan analisa untuk melihat tingkat signifikansinya, sehingga perlu dilakukan proses pembobotan dan normalisasi. Uji coba yang akan dilakukan adalah mengamati fitur mana yang signifikan yang mempunyai akurasi tinggi pada proses klasifikasi.

\subsection{Klasifikasi}

Pada tahap ini dilakukan proses klasifikasi untuk menentukan kelas dari objek. Metode yang digunakan adalah K-Nearest Neighbor dengan menggunakan perhitungan jarak Eucledian. Pada uji coba, dilakukan pengujian untuk jumlah $\mathrm{k}=3$ sampai $\mathrm{k}=7$. Hasil akurasi terbaik diperoleh ketika $\mathrm{k}=5$, sehingga pada pengujian klasifikasi akan menggunakan $\mathrm{k}=5$.

\section{Uji Coba}

Pada penelitian ini dataset yang digunakan adalah citra RGB yang berukuran 400x225. Jumlah dataset yang digunakan adalah 30 citra ikan tuna yang terdiri dari 10 citra bigeye, 10 citra skipjack, dan 10 citra yellowfin. Pengambilan dataset dilakukan secara langsung di PT Aneka Tuna Indonesia yang dilakukan pada siang hari dengan pencahayaan yang cukup. Contoh dataset yang digunakan ditunjukkan pada Gambar 3. Pembagian data latih dan data uji dilakukan dengan menggunakan 10-fold cross validation dari seluruh dataset yang digunakan. Setiap uji coba 1 fold akan menggunakan 27 data latih dan tiga data uji.

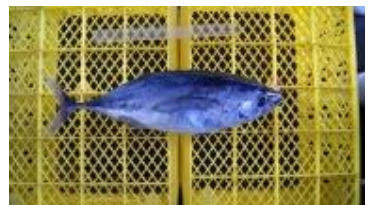

(a)

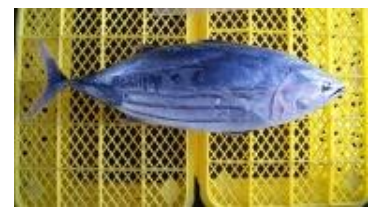

(b)

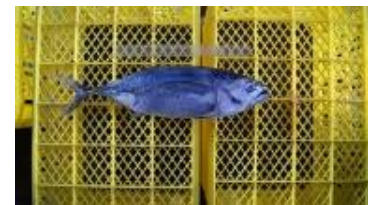

(c)

Gambar 3. Contoh citra ikan tuna. (a) Bigeye; (b) Skipjack; (c) Yellowfin

\subsection{Hasil Pengujian}

Pengujian akan dilakukan pada fitur secara individu baik untuk fitur bentuk maupun titik salien dan pada fitur setelah diintegrasikan. Performa yang diukur pada proses ekstraksi dan integrasi fitur adalah akurasi klasifikasi dan waktu eksekusi. Uji coba yang sudah dilakukan dimulai dari proses input citra, segmentasi, ekstraksi deskriptor bentuk, ekstraksi titik salien, integrasi fitur, dan klasifikasi. Proses pelatihan dilakukan pada tahap klasifikasi berdasarkan deskriptor bentuk yang diujicobakan pada bagian badan, kepala, dan ekor; titik salien yang diujicobakan pada bagian badan, kepala, dan ekor, dan penggabungan keduanya dengan mengambil bagian terbaik dari masing-masing fitur. Hasil dari pelatihan ini berupa model yang digunakan pada saat prediksi kelas dari data uji. 


\subsubsection{Segmentasi}

Sebelum dilakukan segmentasi, citra input dilakukan praproses dengan mentransformasi citra input RGB menjadi citra HSV. Pemrosesan citra selanjutnya hanya menggunakan kanal Hue (H) tanpa menggunakan kanal Saturation (S) dan Value (V) karena pada kanal H objek ikan sudah terdeteksi dengan jelas dan memiliki kontras warna antara objek dengan background sehingga memudahkan dalam melakukan proses segmentasi, Gambar 4(b). Citra H kemudian diubah menjadi citra biner dengan level luminance yang digunakan adalah 0,5. Thresholding citra yang digunakan menggunakan metode Otsu. Untuk mendapatkan hasil segmentasi yang baik, dilakukan proses penghilangan noise dengan mengaplikasikan operasi morfologi yaitu closing untuk menggabungkan objek yang berdekatan, imfill untuk mengisi lubang pada area, serta proses penghilangan area-area kecil dan hanya mengambil satu area terbesar, seperti yang ditunjukkan pada Gambar 4(d).

Pada proses ekstraksi deskriptor bentuk, selain dilakukan uji coba pada hasil segmentasi badan penuh juga dilakukan uji coba hanya mengambil bagian kepala maupun ekor saja. Hal ini dilakukan untuk menganalisis bagian ikan yang mempunyai perbedaan signifikan. Pembagian bentuk ikan dilakukan dengan membagi area objek ikan (bounding box) Gambar 5(a) menjadi sama besar, sehingga menghasilkan area ekor Gambar 5(b) dan area kepala Gambar 5(c).

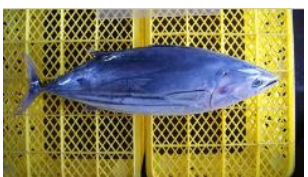

(a)

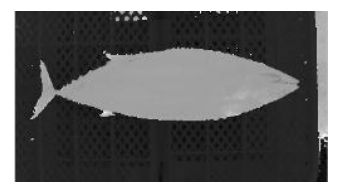

(b)

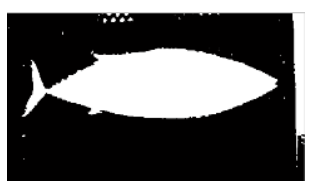

(c)

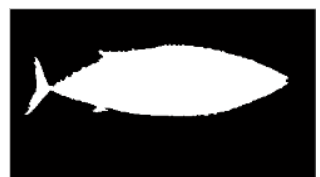

(d)

Gambar 4. Proses Segmentasi Citra (a) Citra Asli; (b) Citra Hue; (c) Citra Biner Ber-noise; (d) Hasil Segmentasi

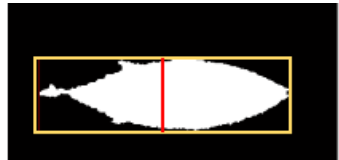

(a)

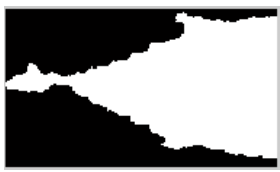

(b)

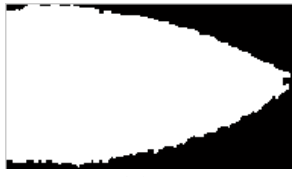

(c)

Gambar 5. Contoh Pemotongan Bagian Ikan (a) Bounding Box pada badan utuh; (b) Bagian Ekor; (c) Bagian Kepala

\subsubsection{Ekstraksi Deskriptor Bentuk}

Ekstraksi deskriptor bentuk dimulai dengan ekstraksi titik tepi objek dan penentuan titik centroid. Jarak antara titik tepi dan centroid akan dijadikan shape signature pada Fourier descriptor.

Hasil uji klasifikasi untuk deskriptor bentuk berdasarkan badan ikan menunjukkan bahwa titik tepi sebanyak 474 dan 478 memiliki akurasi tertinggi sebesar 53,33\% dengan waktu eksekusi kedua titik tepi tersebut masing-masing 8,25 dan 7,82 detik. Hasil uji klasifikasi untuk deskriptor bentuk bagian kepala ditunjukkan pada Gambar 6. Pada pengujian klasifikasi berdasarkan kepala ikan, titik tepi sebanyak 255 memiliki akurasi tertinggi sebesar $90 \%$ dengan waktu eksekusi 7,49 detik. Hasil uji klasifikasi untuk deskriptor bentuk bagian ekor diperoleh titik tepi sebanyak 300 memiliki akurasi tertinggi sebesar 66,67\% dengan waktu eksekusi 8,03 detik.

Hasil uji coba ekstraksi fitur bentuk menunjukkan bahwa bentuk kepala ikan memiliki deskriptor yang signifikan dengan akurasi klasifikasi 90\%. Dengan demikian, pada uji coba integrasi fitur akan menggunakan fitur bentuk dari kepala ikan yang digabungkan dengan titik salien.

\subsubsection{Ekstraksi Titik Salien}

Untuk setiap citra memiliki jumlah titik salien yang berbeda-beda. Total titik salen yang ditemukan di badan ikan sebanyak 2.170 titik, pada bagian kepala saja 560 titik, dan bagian ekor 
saja 528 titik.

Pada pengujian klasifikasi berdasarkan bagian badan, visual dictionary sebanyak 20 memiliki akurasi tertinggi sebesar 73,33\% dengan waktu eksekusi 21,85 detik. Ditunjukkan pada Gambar 7. Pada pengujian klasifikasi berdasarkan bagian kepala, visual dictionary sebanyak 40 memiliki akurasi tertinggi sebesar 70\% dengan waktu eksekusi 20,14 detik. Pada pengujian klasifikasi berdasarkan bagian ekor, visual dictionary sebanyak 25 memiliki akurasi tertinggi sebesar 60\% dengan waktu eksekusi 20,09 detik.

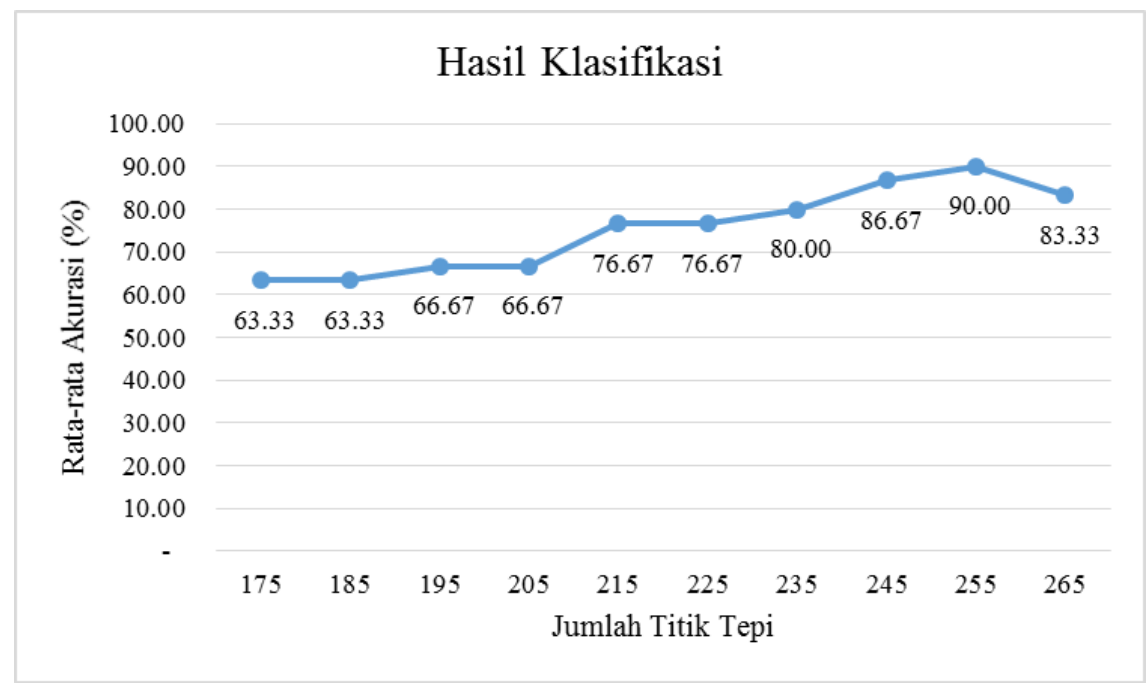

Gambar 6. Rata-rata Akurasi Bagian Kepala Ikan

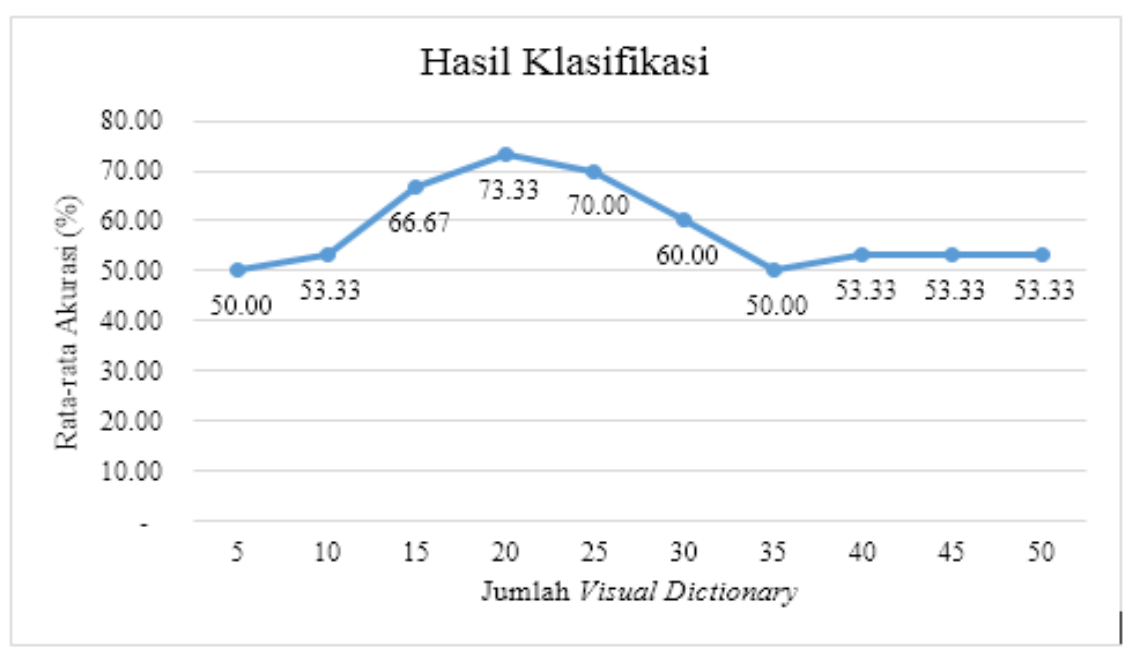

Gambar 7. Rata-rata Akurasi Bagian Badan

Hasil uji coba ekstraksi titik salien menunjukkan bahwa bagian badan memiliki terdapat fitur-fitur signifikan dengan akurasi klasifikasi 73,33\% dengan waktu yang dibutuhkan 21,85 detik. Dengan demikian, pada uji coba integrasi fitur akan menggunakan fitur tersebut untuk diintegrasikan dengan fitur bentuk.

Integrasi fitur dilakukan dengan mengambil bagian dari bentuk dan titik salien yang memiliki nilai akurasi terbaik pada saat pengujian klasifikasi. Di sini fitur bentuk diambil pada bagian kepala ikan dengan jumlah fitur 255. Sedangkan titik salien diambil pada bagian badan ikan dengan jumlah fitur 20. Uji coba integrasi pertama kali menggunakan total fitur 275. Nilai akurasi yang diperoleh sebesar 73,33\%. Uji coba dilakukan dengan memberikan bobot pada fitur bentuk dan titik salien agar mendapatkan nilai akurasi yang lebih baik yang dirumuskan pada persamaan (8). Hasil pengujian menunjukkan dengan memberikan bobot 7 pada fitur 
bentuk $(\alpha)$ dan 1 untuk titik salien ( $\beta$ ) nilai akurasinya meningkat menjadi 83,33\%.

$$
\text { fitur_akhir }=\alpha[\text { fitur_bentuk }] \beta[\text { titik_salien }]
$$

\subsection{Pembahasan}

Hasil dari ekstraksi deskriptor bentuk menunjukkan akurasi klasifikasi yang menggunakan bagian kepala saja lebih baik dari bagian yang lain. Hal ini menunjukkan bahwa bagian kepala memiliki deskriptor bentuk yang signifikan, yaitu pada tingkat keruncingannya.

Hasil pengujian klasifikasi berdasarkan bentuk kepala, jumlah titik tepi 255 memiliki akurasi tertinggi. Hal ini karena pemilihan jumlah titik sebanyak 255 dapat merepresentasikan bentuk yang optimal. Dengan titik tersebut, tepi bentuk menjadi lebih halus dan dapat merepresentasikan bentuk yang aslinya. Semakin banyak titik yang dipilih, maka bentuk akan semakin detail. Akibatnya terdapat nilai-nilai yang kurang penting dalam perhitungan jarak centroid. Apabila jumlah titik yang dipilih terlalu sedikit, maka tidak merepresentasikan bentuk aslinya.

Akurasi klasifikasi juga ditentukan dari pemilihan data latih dan data uji. Akurasi yang paling maksimal diperoleh pada iterasi pengujian fold ke-2 dan ke-3 yaitu mencapai akurasi $100 \%$, sedangkan akurasi yang paling minimal terjadi pada iterasi pengujian ke-8 dengan nilai 56,67\%. Dari hasil pengamatan ini, ikan jenis Bigeye dapat diklasifikasikan dengan baik dibandingkan dengan jenis lainya. Sedangkan jenis Yellowfin sering terjadi kesalahan deteksi jika dilihat dari segi bentuk.

Hasil uji ekstraksi titik salien menunjukkan titik salien yang diambil di seluruh badan ikan memiliki akurasi tertinggi sebesar 73,33\% dibandingkan pada bagian kepala dan ekor. Hal ini berarti karakteristik signifikan dari sebuah citra tersebar di seluruh bagian badan, tidak terpusat di kepala maupun ekor saja. Pemilihan jumlah cluster pada tahapan BOF juga mempengaruhi hasil klasifikasi. Pada bagian badan tersebut, jumlah cluster terbaik adalah 20 . Hal ini berarti dari keseluruhan titik salien yang diekstrak pada semua dataset terdapat kelompok-kelompok yang mewakili karakteristik khusus, dalam hal ini yang paling baik adalah pembagian dalam 20 kelompok. Pengklasteran yang dilakukan menggunakan K-Means Clustering dengan titik pusat awal dilakukan secara random. Kekurangan dari inisialisasi centroid secara random mengakibatkan iterasi perhitugan keanggotaan klaster menjadi tidak menentu, hal ini juga mempengaruhi akurasi klasifikasi dan waktu eksekusi.

Akurasi klasifikasi juga ditentukan dari pemilihan data latih dan data uji. Akurasi yang paling maksimal diperoleh pada iterasi pengujian fold ke-6 yaitu mencapai akurasi 93,33\%, sedangkan akurasi yang paling minimal terjadi pada iterasi pengujian ke-10 dengan nilai 6,67\%. Dari hasil pengamatan ini, ikan jenis Skipjack dapat diklasifikasikan lebih baik dibandingkan dengan jenis lainya. Sedangkan Yellowfin sering terjadi kesalahan deteksi berdasarkan penentuan titik salien.

Uji coba yang sudah dilakukan pada proses integrasi fitur, menunjukkan bahwa dengan memberikan bobot yang lebih tinggi pada fitur bentuk, maka hasil akurasi semakin baik, sedangkan apabila memberikan bobot yang lebih tinggi pada titik salien, maka hasil klasifikasi semakin menurun. Hal ini berarti fitur bentuk lebih dominan terhadap objek ikan dibandingkan dengan titik salien.

\section{Kesimpulan dan Saran}

Bagian objek ikan yang memiliki deskriptor bentuk yang signifikan adalah bagian kepala. Hasil uji coba individu menunjukkan akurasi klasifikasi dari pemilihan bagian kepala sebesar $90 \%$. Nilai akurasi ini lebih tinggi dibandingkan dengan bagian badan dan bagian ekor. Pada ekstraksi titik salien, bagian yang memiliki fitur signifikan terdapat pada badan ikan. Jumlah visual word yang paling optimal adalah 20. Hasil uji coba individu menunjukkan akurasi klasifikasi mencapai $73,33 \%$. Nilai akurasi ini lebih tinggi dibandingkan dengan pemilihan jumlah klaster yang lain. Pada proses integrasi fitur yang mengambil fitur bentuk dan 
titik salien paling optimal dilakukan uji coba pembobotan. Hasil uji coba menunjukkan dengan memberikan bobot $\alpha=7$ dan $\beta=1$ maka akurasi klasifikasi yang diperoleh sebesar $83,33 \%$. Hasil perbandingan pemilihan fitur menunjukkan, fitur bentuk lebih dominan dibandingkan dengan titik salien.

Berdasarkan penelitian yang sudah dilakukan, terdapat beberapa saran yang berguna untuk penelitian-penelitian berikutnya. Pada titik salien yang sudah dideteksi, selain mengambil fitur berdasarkan deskriptor yang sudah diekstrak juga perlu mempertimbangkan pengambilan intensitas warna dan tekstur di area sekitar titik salien. Fitur dengan dimensi yang banyak dapat menyebabkan lambatnya waktu komputasi, sehingga perlu penanganan khusus melalui proses seleksi fitur.

\section{Referensi}

Aakif, A., \& Khan, M. F. 2015. Automatic classification of plants based on their leaves. Biosystems Engineering, 139, 66-75.

Bay, H., Ess, A., Tuytelaars, T., \& Gool, L. V. 2008. Speeded-Up Robust Features (SURF). Computer vision and image understanding, 110(3), 346-359.

Chen, Z., \& Sun, S. K. 2010. A Zernike moment phase-based descriptor for local image representation and matching. IEEE Transactions on Image Processing, 19(1), 205-219.

El-gayar, M. M., \& Soliman, H. 2013. A comparative study of image low level feature extraction algorithms. Egyptian Informatics Journal, 14(2), 175-181.

Hu, M. K. 1962. Visual pattern recognition by moment invariants. Information Theory, IRE Transactions on, 8(2), 179-187.

Hu, Y., \& Li, Z. 2013. An improved shape signature for shape representation and image retrieval. Journal of Software, 8(11), 2925-2929.

Kadir, A. 2015. Leaf Identification Using Fourier Descriptors and Other Shape Feature. Gate to Computer Vision and Pattern Recognition, 1, 3-7.

Li, K., Wang, F., \& Zhang, L. 2015. A New Algorithm for Image Recognition and Classification Based on Improved Bag of Features Algorithm. Optik-International Journal for Light and Electron Optics, 1-9.

Nabizadeh, N., \& Kubat, M. 2015. Brain tumors detection and segmentation in MR images: Gabor wavelet vs statistical features. Computer and Electrical Engineering, 1-16.

Yang, H. Y., Li, Y. W., Li, W. Y., Wang, X. Y., \& Yang, F. Y. 2014. Content-based image retrieval using local visual attention feature. Journal of Visual Communication and Image Representation, 25(6), 1308-1323. 